\title{
Distribution and molecular characterization of Citrus yellow vein clearing virus in Yunnan Province of China
}

\author{
Qin Wang ${ }^{1}$, Yingli Wang ${ }^{1}$, Zhen Yang ${ }^{1}$, Shaoguo $\mathrm{He}^{2}$, Qiang $\mathrm{Wu}^{2}$, Jifen $\mathrm{Li}^{3}$, Zhengwen $\mathrm{Li}^{3}$, \\ and Yan Zhou ${ }^{{ }^{*}}$
}

'Southwest University, Citrus Research Institute, Chongqing 400712, China.

"Corresponding author (zhouyan@cric.cn).

${ }^{2}$ Anyue Lemon Science and Technology Institute, Sichuan 642300, China.

${ }^{3}$ Xinping Yi-Dai Autonomous County Agricultural Bureau, Yuxi 653400, Yunnan, China.

Received: 8 April 2019; Accepted: 27 June 2019; doi:10.4067/S0718-58392020000100133

\begin{abstract}
In 2009, a new citrus viral disease caused by Citrus yellow vein clearing virus (CYVCV) was first discovered in Yunnan province of China. In this study, a survey was conducted in 27 orchards from Yunnan province from April 2017 to September 2018. In all, 45 of a total of 513 citrus samples were tested positive for CYVCV by reverse transcription polymerase chain reaction (RT-PCR). Furthermore, the complete genome sequences of six CYVCV isolates from different hosts were sequenced. Comparisons of the whole genome sequences of these six CYVCV isolates as well as 34 isolates previously reported from around the world revealed the sequence identity ranged from $96.9 \%$ to $99.8 \%$ at nucleotide level, indicating that there is a very low level of sequence heterogeneity among CYVCV isolates of different hosts in Yunnan province.
\end{abstract}

Key words: Citrus viral disease, CYVCV, distribution, molecular characterization.

\section{INTRODUCTION}

Yellow vein clearing disease (YVCD) of citrus, an emerging viral disease was first reported from Pakistan in 1988 in lemon (Citrus xlimon [L.] Osbeck) and sour orange (C. xaurantium L.) (Catara et al., 1993). Subsequently, this disease was also reported in commercial lemon trees in India (Alshami et al., 2003), Turkey (Önelge, 2002), China (Chen et al., 2014) and Iran (Hashmian and Aghajanzadeh, 2017). Currently, YVCD is widely distributed in almost all citrus growing provinces of China and considered the most serious disease affecting lemon production.

Citrus yellow vein clearing virus (CYVCV), a recently described member of the genus Mandarivirus, family Alphaflexiviridae, is considered the causal agent of YVCD (Loconsole et al., 2012). The viral genome consists of a singlestranded positive-sense RNA molecule of around $7.5 \mathrm{~kb}$, with six predicted open reading frames (ORFs) (Loconsole et al., 2012). The infection of CYVCV is usually symptomless in most field citrus cultivars, but it induces strong yellow vein clearing, leaf distortion, water soaking of veins on the ventral side symptoms and significant reduction of fruit yields in lemon and sour orange (Önelge, 2002; Zhou et al., 2017). Although it could also induce vein clearing in the young spring flushes of a few cultivars of mandarin, tangerine and pumelo, the symptoms were reduced and even disappeared after the leaves were matured (Zhou et al., 2017). CYVCV is transmitted through the vegetative propagation of infected buds, scions or rootstocks and by mechanical inoculation of sap extracts onto citrus and herbaceous indicators (Chenopodium quinoa, Ch. amaranticolor, Phaseolus vulgaris and Vigna unguiculata) (Catara et al., 1993; Önelge et al., 2011; Zhou et 
al., 2016). Önelge (2002) suggested that CYVCV could be transmitted by Aphis craccivora and A. spiraecola from lemon to bean (P. vulgaris), and from bean to bean (Önelge, 2002). Recent studies indicated that under controlled conditions, the virus was also transmitted among citrus plants by A. spiraecola, Dialeurodes citri and contaminated tools (Zhang et al., 2018; 2019a; 2019b).

In previous studies, five full sequences of CYVCV isolates were obtained from Yunnan province (Song et al., 2015; Cao et al., 2016; Zhou et al., 2017). Nevertheless, almost all of these isolates were collected from 'Eureka' lemon $(C$. $x$ limon), and the information on the presence and molecular characterization of CYVCV from other citrus cultivars in Yunnan province was still poorly characterized. Therefore, further studies are needed to get a more complete overview of the molecular variability of CYVCV. The present study was undertaken to provide further insight on the distribution of CYVCV in Yunnan province. In addition, the full sequences of six CYVCV isolates obtained from different citrus cultivars in Yunnan province were also used to produce a thorough molecular variability analysis.

\section{MATERIALS AND METHODS}

The field survey and collection of samples were conducted from April 2017 to September 2018. A total of 513 citrus samples were collected from 27 orchards in 9 counties of Yunnan province (Table 1) (Figure 1). Total RNA extracts were obtained from each plant with Trizol reagent (Invitrogen, Carlsbad, California, USA), and used for one-step reverse transcription polymerase chain reaction (RT-PCR) detection with the specific primers VF-1/VR-1 as previously described by Chen et al. (2014). The housekeeping gene cytochrome oxidase (COX) was used as an internal control to validate the effectiveness of the total RNA extracts (Ananthakrishnan et al., 2010).

Table 1. Incidence of Citrus yellow vein clearing virus (CYVCV) in citrus from Yunnan Province of China.

\begin{tabular}{|c|c|c|c|}
\hline \multicolumn{2}{|c|}{ Source } & \multirow[b]{2}{*}{ Cultivar } & \multirow[b]{2}{*}{ Detection rate of CYVCV } \\
\hline City & County & & \\
\hline \multirow[t]{5}{*}{ Honghe } & Jianshui & Nichinan 1 & $4 / 9^{a}$ \\
\hline & & Ponkan & $2 / 11$ \\
\hline & Mile & Gonggan & $0 / 21$ \\
\hline & & Ponkan & $0 / 14$ \\
\hline & & Bingtangcheng & $4 / 15$ \\
\hline \multirow[t]{9}{*}{ Dali } & Binchuan & Or & $5 / 17$ \\
\hline & & Newhall Navel orange & $0 / 10$ \\
\hline & & Marumi kumquat & $0 / 19$ \\
\hline & & Shiranuhi & $0 / 7$ \\
\hline & & Qingpiju & $1 / 11$ \\
\hline & & Aiyuan-38 & $0 / 12$ \\
\hline & & Willking tangor & $0 / 29$ \\
\hline & & Murcott tangor & $0 / 20$ \\
\hline & & Gonggan & $0 / 11$ \\
\hline \multirow[t]{3}{*}{ Zhaotong } & Yongshan & Newhall Navel orange & $0 / 25$ \\
\hline & & Ponkan & $0 / 38$ \\
\hline & & Asumi & $3 / 3$ \\
\hline Lijiang & Yongshen & Bingtangcheng & $3 / 27$ \\
\hline \multirow[t]{8}{*}{ Yuxi } & Huaning & Ponkan & $0 / 41$ \\
\hline & & Newhall Navel orange & $0 / 24$ \\
\hline & & Satsuma & $5 / 37$ \\
\hline & Xinping & Or & $10 / 27$ \\
\hline & & Bingtangcheng & $2 / 38$ \\
\hline & & Newhall Navel orange & $0 / 17$ \\
\hline & & Kanbei & $0 / 5$ \\
\hline & & Aiyuan-38 & $5 / 9$ \\
\hline \multirow[t]{3}{*}{ Puer } & Zhenyuan & Or & $1 / 5$ \\
\hline & & Ponkan & $0 / 4$ \\
\hline & Jiangcheng & Ponkan & $0 / 7$ \\
\hline Total & & & $45 / 513$ \\
\hline
\end{tabular}

${ }^{a}$ Numerator: number of plants infected; denominator: number of test plants used. 
Figure 1. Distribution of Citrus yellow vein clearing virus in Yunnan Province of China between 2017 and 2018 . Found affected by $\operatorname{CYVCV}(\Delta)$, not found affected by $\operatorname{CYVCV}(\Delta)$.

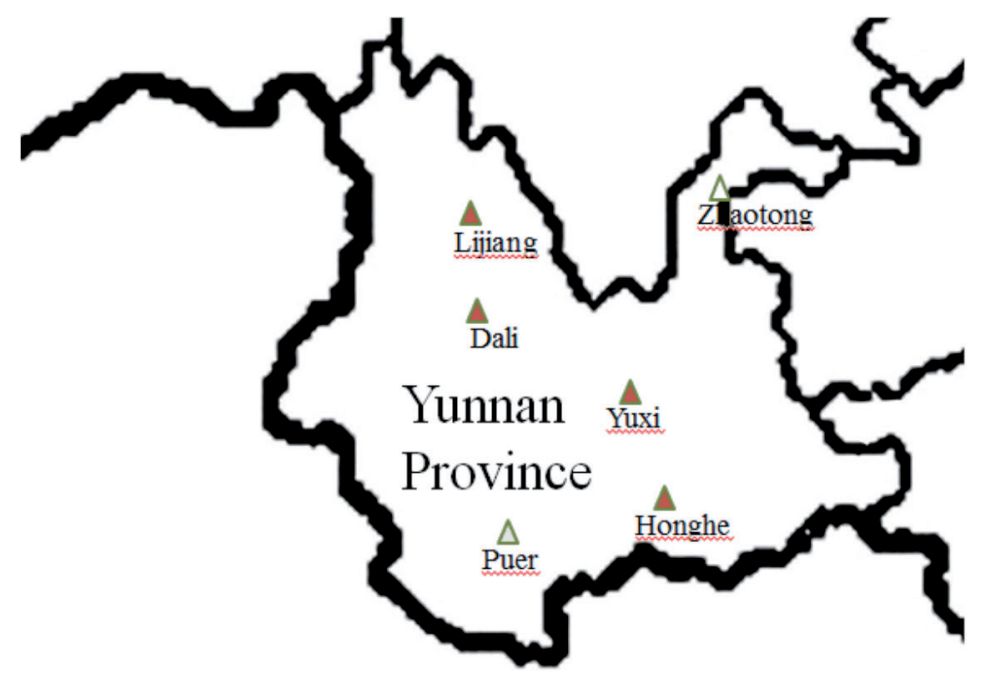

For cloning, six CYVCV-positive samples were randomly selected from different citrus cultivars and geographical origins. Seven sets of overlapping primers were used for genome amplification, as described previously (Loconsole et al., 2012). PCR amplicons were purified and cloned into pGEM-T easy vector (Promega Corp., Madison, Wisconsin, USA). Three clones per fragment were custom sequenced (Beijing Genomics Institute, Shengzhen, Guangdong, China). Complete genome sequences were assembled using BioEdit 7.0.5.3 (Tom Hall, Ibis Therapeutics, Carlsbad, California, USA) and deposited in GenBank (National Center for Biotechnology Information [NCBI], Bethesda, Maryland, USA) under accession numbers MK415923 to MK415928.

Multiple nucleotide sequence alignments of the complete genome of the six CYVCV isolates from this study, plus the $34 \mathrm{CYVCV}$ isolates previously reported from around the world (Table 2), Indian citrus ringspot virus (ICRSV, AF406744, HQ324250) and Potato virus X (PVX, M72416) were conducted separately with CLC Genomics Workbench 8.5.1. (https://www.qiagenbioinformatics.com/).

Phylogenetic analysis of the genomic sequences, RNA-dependent RNA polymerase (RDRP) and coat protein (CP) was performed with the MEGA, version 7.0.21, analysis package (Tamura et al., 2013) by using the neighborjoining (NJ), with 1000 bootstrap replicates as the test of phylogeny. The cut-off value for the condensed tree was $60 \%$.

\section{RESULTS AND DISCUSSION}

COX was detected in all of total RNA extracts from citrus plants, and CYVCV was detected in $8.77 \%$ of the collected samples (45 samples were positive out of the 513 samples tested). Furthermore, CYVCV was found in 7 of total 9 surveyed counties, demonstrating that the virus is widely distributed in Yunnan province. In surveyed citrus cultivars, the most frequently infected cultivar was Asumi $(C$. $\times$ sinensis $\times C$. reticulata $)$, with an infection rate of $100 \%$, followed by 'Nichinan 1' (C. reticulata, 44.44\%), 'Or' (C. reticulata $\times C$. $\times$ sinensis, 32.65\%), 'Aiyuan-38' (C. reticulata $\times C$. xinensis, 23.81\%), 'Satsuma' (C. unshiu, 13.51\%), 'Bingtangcheng' (C. sinensis, 11.25\%), 'Qingpiju' (C. reticulata, $9.09 \%$ ) and 'Ponkan' (C.reticulata $1.74 \%)$. CYVCV was not found on 'Newhall Navel' orange (C. $\times$ sinensis), 'Gonggan' (C. reticulata), 'Willking tangor' (C.reticulata $\times$ C. $\times$ sinensis), 'Murcott tangor' $(C$. reticulata $\times C . \times$ sinensis), 'Marumi kumquat' (Fortunella japonica [Thunb.] Swingle), 'Shiranuhi' (C.reticulata $\times$ C. $\times$ sinensis) and 'Kanbei' (C.reticulata $\times$ C. $\times$ sinensis). Furthermore, the young spring flushes of CYVCV-infected 'Satsuma', 'Or' and 'Bingtangcheng' expressed mild to moderate vein clearing and chlorosis, respectively. However, these symptoms were reduced and even disappeared after the leaf matured.

As shown in Table 2, the genome size of CYVCV isolates collected from YN-KPJ was $7531 \mathrm{bp}$, other isolates including BJ-HMR, JS-RN1, HP-MRJ, BJ-WG, BJ-QPJ, were 7529 bp in length. Analysis of the genome sequences predicted six 
Table 2. Accession numbers, host, and collection area of Citrus yellow vein clearing virus isolates used in this study for molecular variability analysis.

\begin{tabular}{|c|c|c|c|c|}
\hline Isolate & Host & Origin & Accession number & Length (bp) \\
\hline YN-KPJ & Satsuma & Yunnan & MK415923 & 7531 \\
\hline BJ-HMR & Aiyuan-38 & Yunnan & MK415924 & 7529 \\
\hline JS-RN1 & Nichinan 1 & Yunnan & MK415925 & 7529 \\
\hline HP-MRJ & Asumi & Yunnan & MK415926 & 7529 \\
\hline BJ-WG & Or & Yunnan & MK415927 & 7529 \\
\hline BJ-QPJ & Qingpiju & Yunnan & MK415928 & 7529 \\
\hline SC-EL & Eureka lemon & Sichuan & KX156748 & 7529 \\
\hline SC-NH & Newhall navel orange & Sichuan & KX156749 & 7529 \\
\hline AY204 & Eureka lemon & Sichuan & MG878869 & 7529 \\
\hline CQ-PO & Zaoyangxiaoye trifoliate & Chongqing & KX156735 & 7529 \\
\hline CQ-TA & Tarocco blood orange & Chongqing & KX156736 & 7529 \\
\hline YN-NH & Newhall navel orange & Yunnan & KX156752 & 7529 \\
\hline YN-BTC & Bingtangcheng & Yunnan & KX156750 & 7529 \\
\hline YN-EL & Eureka lemon & Yunnan & KX156751 & 7529 \\
\hline YN & Eureka lemon & Yunnan & KP313242 & 7529 \\
\hline CYVCV-RL & Eureka lemon & Yunnan & KP120977 & 7529 \\
\hline JX-NH & Newhall navel orange & Jiangxi & KX156747 & 7529 \\
\hline JX-NF & Nanfengmiju tangerine & Jiangxi & KX156746 & 7531 \\
\hline JX & Satsuma mandarin & Jiangxi & KX378154 & 7529 \\
\hline HN-GXP & Guanximiyou pummelo & Hunan & KX156744 & 7529 \\
\hline HN-STJ & Shatangju tangerine & Hunan & KX156745 & 7531 \\
\hline $\mathrm{HU}$ & Sweet orange & Hunan & KT124646 & 7530 \\
\hline GX-STJ & Shatangju tangerine & Guanxi & KX156742 & 7529 \\
\hline GX-GXP & Guanximiyou pummelo & Guanxi & KX156741 & 7531 \\
\hline GX-SA & Satsuma & Guanxi & KX156734 & 7529 \\
\hline GD-STP & Shatianyou pummelo & Guangdong & KX156740 & 7531 \\
\hline GD-STJ & Shatangju tangerine & Guangdong & KX156739 & 7529 \\
\hline GD-JG & Jiaogan mandarin & Guangdong & KX156738 & 7531 \\
\hline FJ-PK & Ponkan & Fujian & KX156737 & 7531 \\
\hline GZ-GXP & Guanximiyou pummelo & Guizhou & KX156743 & 7531 \\
\hline $\mathrm{ZJ}-1$ & Bergamot & Zhejiang & KY933794 & 7529 \\
\hline $\mathrm{ZJ}-2$ & Bergamot & Zhejiang & KY933795 & 7529 \\
\hline $\mathrm{ZJ}-3$ & Aiyuan-38 & Zhejiang & KY933796 & 7529 \\
\hline $\mathrm{ZJ}-4$ & Aiyuan-38 & Zhejiang & KY933797 & 7529 \\
\hline KPMI & Kinnow & India & KT696513 & 7531 \\
\hline PALA & Sweet orange & India & KT696512 & 7531 \\
\hline RMGI & Malta & India & KT696511 & 7531 \\
\hline ECAI & Etrog citron & India & KT696510 & 7560 \\
\hline IS & Eureka Cascade lemon & Pakistan & KT345342 & 7529 \\
\hline PK & Galgal lemon & Pakistan & KP313241 & 7529 \\
\hline
\end{tabular}

open reading frames (ORFs) on the positive strand, identifying a 5' untranslated region (UTR) and a 3' UTR of 37 nt, followed by a poly(A) tail. The genome organization of all of these isolates and those published elsewhere was consistent (Loconsole et al., 2012; Cao et al., 2016; Zhou et al., 2017). Alignment showed that all 5' UTRs started with GAAAG, and all 6 ORFs of these CYVCV isolates started with an ATG codon and terminated either with a TAA stop codon (ORFs 1,4 and 5) or with a TGA stop codon (ORF 2,3 and 6).

Sequence alignments showed that the six CYVCV isolates shared nucleotide sequence identities with ICRSV-K1 of $72.1 \%$ to $72.6 \%$ and with ICRSV-Pu of $71.9 \%$ to $72.5 \%$ belonging to the same genus (Mandarivirus), and with PVX (representative member of the same family Alphaflexiviridae) of less than $50.4 \%$. These six CYVCV isolates shared high nucleotide identities with three CYVCV isolates of Yunnan 'Eureka' lemon for the whole genome (98.2\% to 99.7\%). Furthermore, sequence analysis showed that these six CYVCV isolates shared high nucleotide identities with $34 \mathrm{CYVCV}$ isolates for the whole genome (97.1\% to $99.8 \%$ ), 5' UTR (92.5\%-100\%), 3' UTR (100\%), and each of the six ORF (93.5\% to 100\%). At the amino acid level, these six CYVCV isolates also shared high identities with the same 34 CYVCV isolates for ORF1 (97.6\%-100\%), ORF2 (96\%-100\%), ORF3 (94.5\%-100\%), ORF4 (96.7\%-100\%), ORF5 (96.0\%-99.7\%), and ORF6 (93.3\%-99.6\%). 
In phylogenetic trees derived from complete nucleotide sequences (Figure 2) of available Mandariviruses (ICRSV-K1 and ICRSV-Pu) and PVX, the representative member of the same family Alphaflexiviridae, all of CYVCV isolates grouped together as a sister branch. All of CYVCV isolates from China were phylogenetically distinct from the isolates from Turkey and Pakistan, and clustered together in the same clade. However, CYVCV isolates from Yunnan province did not show a relationship with the geographic origin of the sampled trees. Moreover, according to the host-species of the isolates, no clear clustering was observed in the phylogenetic trees generated by Neighbor-Joining methods. Phylogenetic analyses of the RDRP and CP amino acid sequences recapitulated results seen for the complete nucleotide sequences.

Figure 2. Phylogenetic tree generated by the neighbor-joining method from the alignment of the genome nucleotide sequences of Citrus yellow vein clearing virus (CYVCV) and members belonging to the same genus, Mandarivirus (Indian citrus ringspot virus, ICRSV), and the same family, Alphaflexiviridae (Potato virus X, PVX), respectively, using MEGA (version 7.0.21). Bootstrap values for 1000 replicates are indicated at the main branches. Branch length is proportional to number of nucleotide changes (bar). Accession numbers of reference sequences are listed in Table 2.

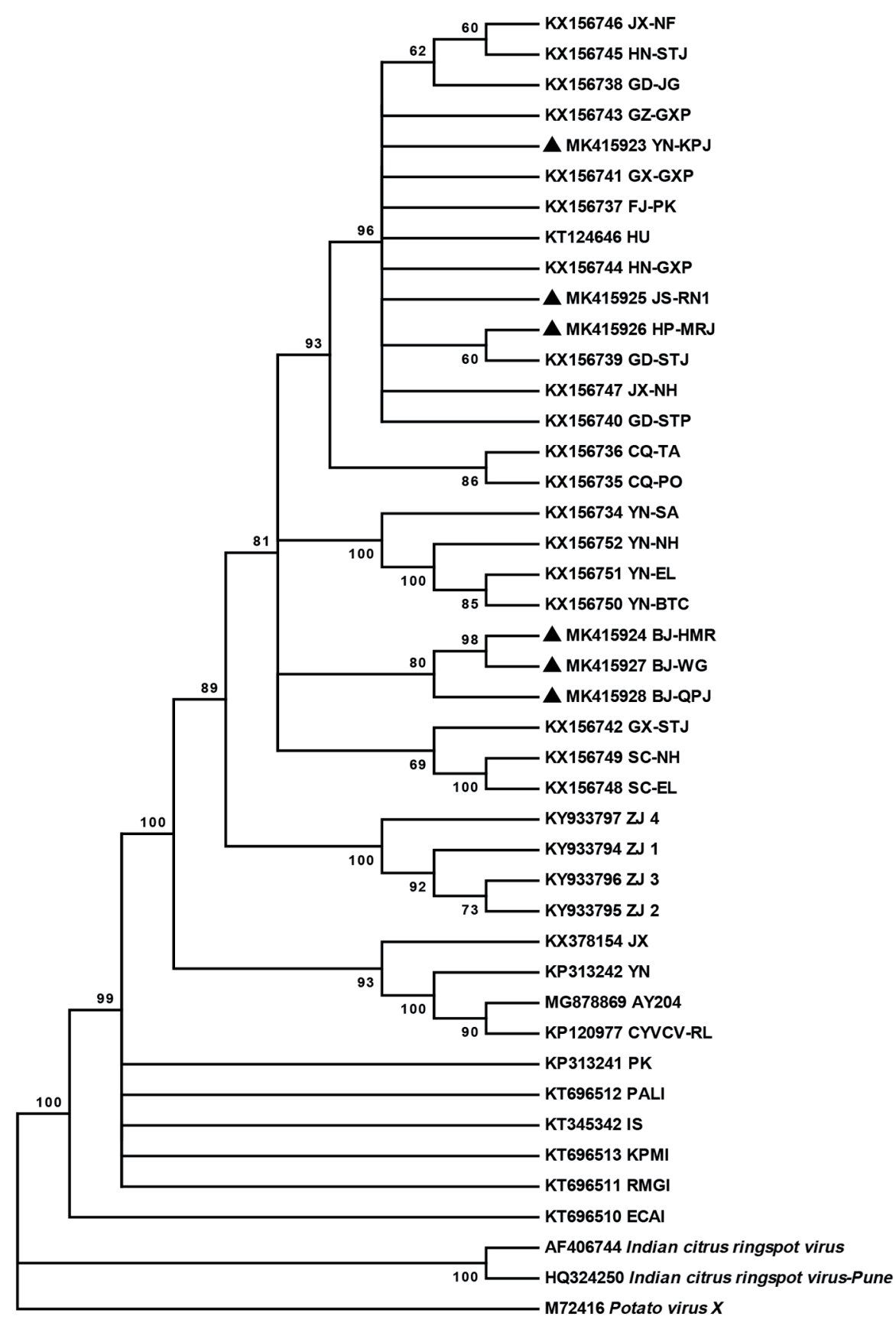


CYVCV, an emerging citrus virus, was first recognized in Yunnan province of China during the past ten years (Chen et al., 2014), but the molecular properties of CYVCV obtained from Yunnan province are poorly characterized. In this study, a large number of samples were collected from 29 citrus orchards in Yunnan province for determining the incidence of CYVCV. The results of this study proved that the occurrence of CYVCV was widely spread in Yunnan province, some citrus cultivars were infected CYVCV including lemon. In this study, sequence analysis showed that six CYVCV isolates from Yunnan province shared high nucleotide identity with other $34 \mathrm{CYVCV}$ isolates, which were deposited in GenBank for the whole genome. The result suggested that there is genetic stability among CYVCV isolates of different host. Furthermore, the phylogenetic tree separated all of the CYVCV isolates from China into the same group, without any clear clustering according to host-species or geographic origin. The results also indicated the movement of vegetative propagative materials or grafting of infected plants was also probably one of the important routes of CYVCV transmission in China.

\section{CONCLUSIONS}

The results of this study revealed very low level of nucleotide sequence diversity of Citrus yellow vein clearing virus in Yunnan province. This finding provides new genomic information for understanding virus epidemiology and evolution.

\section{ACKNOWLEDGEMENTS}

This work was partially supported by Intergovernmental International Science, Technology and Innovation (STI) Collaboration Key Project of China's National Key R\&D Programme (NKP) (2017YFE0110900), Overseas Expertise Introduction Project for Discipline Innovation (111 Center) (B18044) and Fundamental Research Funds for the Central Universities (XDJK2018AA002).

\section{REFERENCES}

Alshami, A.A.A., Ahlawat, Y.S., and Pant, R.P. 2003. A hitherto unreported yellow vein clearing disease of citrus in India and its viral etiology. Indian Phytopathology 56:422-427.

Ananthakrishnan, G., Venkataprasanna, T., Roy, A., and Brlansky, R.H. 2010. Characterization of the mixture of genotypes of a Citrus tristeza virus isolate by reverse transcription quantitative real-time PCR. Journal of Virological Methods 164:75-82. doi:10.1016/j.jviromet.2009.12.001

Cao, M.J., Wu, Q., Atta, S., Su, H.N., Yu, Y.Q., Chen, H.M., et al. 2016. First molecular evidence of Citrus yellow vein clearing virus from citrus in Punjab, Pakistan. Plant Disease 100:504. doi:10.1094/PDIS-05-15-0609-PDN.

Catara, A., Azzaro, A., Davino, M., and Polizzi, G. 1993. Yellow vein clearing of lemon in Pakistan. p. 364-367. In International Organization of Citrus Virologists (IOCV) Conference. 12 $2^{\text {th }}$ IOCV Conference, Riverside. University of California, Riverside, California, USA.

Chen, H.M., Li, Z.A., Wang, X.F., Zhou, Y., Tang, K.Z., Zhou, C.Y., et al. 2014. First report of Citrus yellow vein clearing virus on lemon in Yunnan, China. Plant Disease 98:1747. doi:10.1094/PDIS-04-14-0343-PDN.

Hashmian, B.S.M., and Aghajanzadeh, S. 2017. Occurrence of Citrus yellow vein clearing virus in citrus species in Iran. Journal of Plant Pathology 99:290.

Loconsole, G., Onelge, N., Potere, O., Giampetruzzi, A., Bozan, O., Satar. S., et al. 2012. Identification and characterization of Citrus yellow vein clearing virus, a putative new member of the genus Mandarivirus. Phytopathology 102:1168. doi:10.1094/PHYTO-06-12-0140-R.

Önelge, N. 2002. First report of yellow vein clearing of lemons in Turkey. Journal of Turkish Phytopathology 32:53-55.

Önelge, N., Satar, S., Elibüyük, Ö., Bozan, O., and Kamberoglu, M. 2011. Transmission studies on Citrus yellow vein clearing virus. In International Organization of Citrus Virologists (IOCV) Conference. $18^{\text {th }}$ IOCV Conference. 3 p. University of California, Riverside, California, USA.

Song, Z., Kurth, E.G., Peremyslov, V.V., Zhou, C.Y., and Dolja, V.V. 2015. Molecular characterization of a Citrus yellow vein clearing virus strain from China. Archives of Virology 160:1811-1813. doi:10.1007/s00705-015-2423-1.

Tamura, K., Stecher, G., Peterson, D., Filipski, A., and Kumar, S. 2013. MEGA6: molecular evolutionary genetics analysis version 6.0. Molecular Biology and Evolution 30:2725-2729. doi:10.1093/molbev/mst197.

Zhang, Y.H., Liu, Y.J., Wang, Y.L., Wang, Q., He, S.G., Li, X.Y., et al. 2019a. Transmissibility of Citrus yellow vein clearing virus by contaminated tools. Journal of Plant Pathology 101:169-171. https://doi.org/10.1007/s42161-018-0141-8.

Zhang, Y.H., Liu, C.H., Wang, Q., Wang, Y.L., Zhou, C.Y., and Zhou, Y. 2019b. Identification of Dialeurodes citri as a vector of Citrus yellow vein clearing virus in China. Plant Disease 103:65-68. doi:10.1094/PDIS-05-18-0911-RE. 
Zhang, Y.H., Wang, Y.L., Wang, Q., Cao, M.J., Zhou, C.Y., and Zhou, Y. 2018. Identification of Aphis spiraecola as a vector of Citrus yellow vein clearing virus. European Journal of Plant Pathology 152:841-844. doi:10.1007/s1065.

Zhou, Y.,Chen,H.M.,Cao,M.J., Wang,X.F., Jin,X.,Liu, K.H.,et al. 2017.Occurrence, distribution, and molecular characterization of Citrus yellow vein clearing virus in China. Plant Disease 101:137-143. doi:10.1094/PDIS-05-16-0679-RE.

Zhou, Y., Ma, D.D., Chen, H.M., Wang, X.F., He, S.G., and Zhou, C.Y. 2016. A rapid and efficient purification of Citrus yellow vein clearing virus by sucrose cushion ultracentrifugation. Journal of Plant Pathology 98:159-161. 